\section{Social capital and internationalization of family SMEs in Campeche, México: a qualitative comparative analysis}

Selina Salazar Cámara ${ }^{1}$

David Martín Ruiz ${ }^{1}$

Francisco Acedo González ${ }^{1}$

\section{Abstract}

Purpose - To study the internationalization of family SMEs in Mexico.

Theoretical framework - Our review examines the relational approach to internationalization and the strategic approach to family businesses. It covers three types of social capital, market orientation, and international business orientation.

Design/methodology/approach - This is a fuzzy-set qualitative case study. Seven family SMEs from the fishing sector in Campeche, Mexico, compose the sample.

Findings - Linking is determining factor for internationalization. The cessation of internationalization occurs in family businesses because of a lack of international entrepreneurship, the family's presence, and a lack of vertical links.

Practical \& social implications - This study expands the research on internationalization in family SMEs in an emerging economy context, empirically demonstrating how the analyzed exporters' social capital links directly influence their activity. For business professionals, the challenge is to manage their links abroad. Our results show that links play a crucial role in internationalization in this context. Exporters that have not internationalized are advised to strengthen their connections with key government institutions.

Originality/value - We show that there is more than one optimal way for family SMEs to succeed in internationalization. Research on the internationalization of family businesses in Mexico is very scarce. Thus, this study responds to calls for further research on the internationalization of SMEs in emerging economies.

Keywords - Internationalization, Family Businesses, SMEs, Emerging Economies, QCA, Business Organization and Marketing

1. University of Seville, Business Organization and Marketing, Seville, Spain

How to cite:

Salazar Cámara, S., Martín Ruiz, D., Acedo González, F., (2021). SOCIAL CAPITAL AND INTERNATIONALIZATION OF FAMILY SMES IN CAMPECHE, MEXICO: A QUALITATIVE COMPARATIVE ANALYSIS. Revista Brasileira de Gestão de Negócios, 23(2), firstpage-lastpage.
252

Received on:

06/07/2019

Approved on:

$12 / 30 / 2020$

Responsible Editor:

Prof. João Maurício Gama

Boaventura

\section{Evaluation process:}

Double Blind Review

\section{Reviewers:}

Lidia Danik. One of the reviewers decided not to disclose his/her identity.

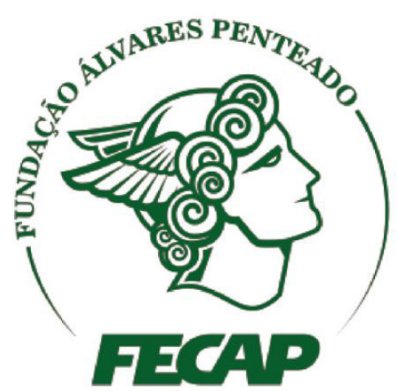

Revista Brasileira de Gestáo de Negócios

https://doi.org/10.7819/rbgn.v23i2.4104 


\section{Introduction}

Although there are several contributions of interest on the internationalization of family businesses from the 1990s, the knowledge about the internationalization of family businesses (hereinafter FBs) from emerging economies remains limited (Carney, Essen, Gedajlovic, \& Huegens, 2015; Essen, Carney, \& Gedajlovic, 2015; Sabah, Carsrud, \& Kocak, 2014; Tasavori, Zaefarian, \& Eng, 2018).

The processes of family-owned small and medium enterprises (SMEs) are different from in other types of enterprises (Abdellatif, Amann, \& Jaussaud, 2010; Hennart, Majocchi, \& Forlani, 2019). In addition to the main differences due to their family nature, size, and resources, this type of firm is more prone to social capital issues (Kontinen \& Ojala, 2011a). This is of particular interest in emerging economies, where there are often unstable institutional environments, frequent changes in the legal system, and a large black economy (Smallbone \& Welter, 2001). These increase the uncertainty associated with the internationalization process.

We find a gap in the literature on the internationalization of family SMEs in emerging economies based on the relational approach. Some studies have shown that networks are a decisive element in FBs seeking out and taking advantage of international opportunities (Coviello, 2006; Kontinen \& Ojala, 2011b; Musteen, Francis, \& Datta, 2010). However, there is insufficient knowledge about the different types of social capital and how they influence the internationalization of FBs (Gittins, Lang, \& Sass, 2015). Their roles may vary depending on the family firm's identity (Uhlaner, Matser, Berent, \& Flören, 2015).

This research seeks to fill this gap in the literature, by focusing on family SMEs, specifically in the fishing sector in the state of Campeche, Mexico, and their internationalization process. Our main objective is to identify the existing relationships between the different types of social capital (bonding, bridging, and linking), international entrepreneurship, and market orientation, and how these variables influence the promotion or cessation of internationalization by SMEs.

The contributions of this study are the following. First, we contribute to understanding the different types of social capital in family firms. Second, we introduce new variables - such as market orientation, international entrepreneurship, bonding, linking, and bridging - to examine how they influence the promotion or cessation of internationalization. By investigating these different organizational configurations, we show more than one optimal way for FBs to achieve successful internationalization results.

In addition, this study focuses on the dynamics of networks and international entrepreneurship in relation to the process of internationalization at an advanced stage. Thus, it complements prior works on new ventures (Ibeh \& Kasem, 2011; Paul \& Rosado-Serrano, 2019) and completing the whole internationalization process (Johanson \& Vahlne, 2009; Vahlne \& Johanson, 2013).

Most of the existing studies have examined the internationalization of family SMEs and their networks in the context of developed markets (Kontinen \& Ojala, 2011a, 2011b). But there have been few studies on emerging countries, where companies use it as a growth and development strategy. Our research focuses on Mexico, where like in most developing countries the majority of firms are SMEs and FBs (Reyna, Vázquez, \& Valdés, 2012). Research is scarce in this context, so we respond to calls for more in-depth studies on internationalization in emerging economies (Kiss, Danis, \& Cavusgil, 2012; Rienda, Claver, Quer, \& Andreu, 2019).

SMEs are characterized by limited financial resources, a focus on their home country, and limited geographical coverage. They lack the resources required to expand operations beyond their domestic markets (Dar \& Mishra, 2020). Most academic studies on FBs in Mexico have focused on describing the characteristics that increase the longevity to this type of business. Despite there being many examples of the internationalization of FBs in different areas, little has been written about the internationalization of Mexican FBs (Maciel, 2013).

Mexican family SMEs require a high level of knowledge and communication. Among their primary values are honesty, trust, efficiency, and a great sense of belonging (Ramos, Qintero, \& Figueroa, 2008). Regarding their social capital, some findings indicate that this results from relationships between the family and other business members, which are strengthened when they commit to new projects (Ramírez \& Fonseca, 2010).

However, there is great difficulty in accessing information on Mexican family SMEs at a public and institutional as well as at a business level, since there are no established databases and there is distrust on the part 
of businesspeople (Martin-Reyna, \& Durán-Encalada, 2012). Likewise, the companies generally lack a relevant organizational structure and strategic planning at a structural level because they often do not look beyond the short term horizon. Therefore, improvisation prevails in these companies (Hernández, Mendoza, \& Salazar, 2015). Among their financial disadvantages, there is a low level of reinvestment and they usually refuse to open up to external capital. Among their cultural disadvantages, they are reluctant to change for fear of the unknown. Both are reflected in the process of generational succession, which is usually not planned.

This study also applies a configurational approach by conducting a fuzzy-set qualitative comparative analysis (hereinafter fsQCA). fsQCA has been widely used as a tool for categorizing antecedents into causal recipes (Cheng, Chang, \& Chu, 2013). Complex phenomena - such as internationalization - are often more accurately described as following on from combinations of antecedent conditions. Moreover, fsQCA is an approach that considers asymmetric relationships between the antecedents and the outcome, offering a useful method to address the research . In this case, we acknowledge that the factors leading to internationalization may be different from the factors leading to non-internationalization. The fsQCA approach has already been used to investigate this topic (Kraus, Mensching, Calabrò, Cheng, \& Filser, 2016).

Finally, from the managerial point of view, we provide a number of practical contributions for family entrepreneurs in the fishing sector to understand the factors that intervene in driving or preventing their internationalization. Given the industry's importance and low competitiveness, this study fills a knowledge gap by adopting a practical approach to the region and the industry.

\section{Theoretical Foundations}

\section{I Addressing internationalization in FBs}

Studies of the internationalization process present different approaches. For instance, the resource-based view sees FBs as unusual, complex, dynamic, and rich in intangible resources. This theory states that many of the competitive advantages of FBs are rooted in the family and the organizational processes that take place within it. This approach also provides a theoretical model that analyzes relationships at different levels within and outside the company and its assets, strategies, and sustainable competitive advantages.

According to the, RBV, competitive advantages arise when a company implements a strategy that generates more value than its competitors and cannot be replicated. In the case of FBs, the differentiating resource may be their three different levels of social capital. The relational aspect is considered an intangible asset and can be even more important than physical capital and inventory (Steier, 2001).

However, it is interesting to observe how other approaches have evolved towards a network perspective (Vahlne \& Johanson, 2013, 2019). In this process, firms need to identify opportunities, deploy resources, and acquire knowledge to advance in their international commitment. Recent literature shows that internationalization is an essential strategic element in pursuing growth (Arregle, Duran, Hitt, \& Essen, 2017). However, most studies assume that family firm internationalization follows the Uppsala model of internationalization (Johanson \& Vahlne, 1977). This perception of the internationalization process is in line with family firms' long-term orientation (Stieg, Cesinger, Apfelthaler, Kraus, \& Cheng, 2018). According to the general tendency, social capital approaches may be of particular interest in a FB because of the unification of ownership and management (Kontinen \& Ojala, 2011a; Salvato \& Melin 2008), as well as contributing to diminishing the risk of this type of decision (Stieg et al., 2018).

Thus, we assume that networks influence family firms' strategic decisions, allowing the exchange of resources between diverse members and serving as bridges into foreign markets, providing new opportunities and the motivation to become international (Johanson \& Vahlne, 2009). Awareness of this issue has led to entrepreneurs identifying and exploiting new global opportunities. There are works on international entrepreneurship and its promotion through relational networks (Coviello, 2006). These use the network internationalization model (Crick \& Spence, 2005), explaining how business networks act as a bridge into foreign markets. Therefore, we assume that networks are crucial for identifying innovative and creative opportunities that will translate into superior financial performance regardless of size or time pursuing internationalization (Kraus et al., 2016; McDougall \& Oviatt, 2000). 
In the case of FBs, entrepreneurial attitudes can be motivated by various factors, including: (i) the longterm nature of ownership, which allows them to dedicate the resources needed for innovation and risk-taking, thus fostering their entrepreneurial spirit (Zahra, Hayton, \& Salvato, 2004); (ii) the kinship ties that are unique to FBs and that can have a positive effect on the recognition of business opportunities; and (iii) the organizational culture, composed of values, beliefs, and goals rooted in the family, its history, and its present social relationships (Hall, Melin, \& Nordqvist, 2001).

According to Kontinen and Ojala (2011b), internal family ties are a burden for entrepreneurship, whereas external partners are crucial for expanding into other markets. A higher or lower level of entrepreneurship will depend on the network established outside the organization, but above all on the dominant group - the family - since it will play an essential role in the decisionmaking process when crossing borders (Casillas, Acedo, $\&$ Moreno, 2007).

\subsection{Internationalization of family SMEs in emerging economies}

Most of the existing research on the internationalization of FBs and the role of networks has been conducted in developed countries (Tasavoriet, et al., 2018). There is a gap in the empirical research concerning the internationalization of family firms from emerging economies (Carney et al., 2015; Essen et al., 2015; Sabah et al., 2014). The critical issue regarding internationalization in developing countries is the role of culture (Tasavori et al., 2018).

SMEs within emerging economies show high dependence on international trade (Senik, ScottLadd, Entrekin, \& Adham 2011). They have a strong tendency to undertake internationalization at an early stage (Ahlstrom, Bruton, \& Yeh 2007) and face more significant challenges due to their limited resources (Claver, Rienda, \& Quer, 2008; Kontinen \& Ojala, 2011a). Family SMEs play a vital role as drivers of the global economy. Despite their limitations due to their size, nature, and resources, they are creators of employment and social development in emerging countries thanks to their international operations (Ahlstrom et al., 2007; Bruton, Ahlstrom, \& Obloj, 2008). Thus, it is interesting to study the behavior of family SMEs in the internationalization process, and how social capital empowers these companies both internally (ease of decision making, conflict management, shared vision, etc.) and externally (Calabrò \& Mussolino, 2013; Segaro, Larimo, Jones, 2014).

In Mexico, society is characterized by low levels of trust and high aversion to risk, so businesses often show reluctance to share information. Within companies, power relationships are generally hierarchical, and the work environment is collectivist (Hofstede, Hofstede, \& Minkov, 2010). Therefore, there is a tendency for people to resist change.

Loyalty and social relationships are highly valued, both inside and outside companies, given Mexico's collectivist nature. Therefore, social capital is considered to be just as essential as human and physical capital to succeed in Mexico (Zapata-Cantu, 2020). From an institutional perspective, emerging markets are generally characterized by an immature and unstable institutional framework. Companies are influenced by market forces when making strategic decisions, such as on internationalization. In addition, it is common to be influenced by formal and informal institutional factors. One example of an influential informal factor is the personal connection between the company and the institutional environment. In emerging markets such as China, these links are called "guanxi," and they are considered a primary resource to compensate for the lack of a competitive advantage (Meyer \& Peng, 2016; Yan, Zhu, Fan, \& Kalfadellis, 2018).

Given the importance of companies' relational links in emerging market contexts, we examine the following variables: social capital at its three levels (bonding, bridging, and linking), international entrepreneurship, and market orientation. We aim to discover how these internal and external relationships occur in family SMEs in the fishing sector. Some authors have shown that in emerging economies such as Mexico, institutional ties, and specifically public officials, have high discretionary power that affects internationalization decisions, including the level of international entrepreneurship of companies (Nuruzzaman, Singh, \& Gaur, 2020; Yan, et al., 2018).

\subsection{Social capital in family SMEs}

Acquiring market knowledge is indispensable for a company to effectively search for international opportunities (Wiklund \& Shepherd, 2003). Also, it 
is relatively difficult to transfer the tacit knowledge of a company. That is why the view of the company as a social community arises, since it is the creator of knowledge, reduces risks, and encourages cooperative behavior through social capital (Prashantham \& Young, 2011).

Social capital influences the efficiency of a firm and can increase profitability and growth, with better communication in business, efficient collective actions, improved stock management, better access to resources, and reductions in transaction costs (Gamage et al., 2020; Meng, Rieckmann, \& Li, 2016). Social capital encompasses the face-to-face relationships established between individuals based on norms, trust, and reciprocity; it is in itself the wealth derived from the social life of an individual or group of individuals and their relationships, as well as the position they occupy within these (Nordstrom \& Steier, 2015).

Since families are social entities that endure across generations, they can rely on lasting shared meanings, including values, norms, and beliefs, to develop and shape their social capital (Erdogan, Rondi, \& Massis, 2020). This capital refers to both the inner and inter-organizational relationships of FBs that provide various internal benefits: reduced transaction costs, ease of information flows, and the creation of knowledge. External advantages are the success of alliances, increased trust, and information flows between parties (Arregle, Hitt, Sirmon, \& Very, 2007).

As highlighted, FBs' social capital is a deeply embedded and tacit resource and extremely difficult to imitate. For these reasons, it is considered a source of competitive advantage for $\mathrm{FBs}$ and a potential lever for strategic organizational processes such as internationalization (Rondi, Debellis, Massis, \& Garzoni, 2020). Evidence suggests that social capital networks provide vital resources for the internationalization of SMEs, as they are a mechanism for acquiring, assimilating, and transforming knowledge and resources (Prashantham $\&$ Young, 2011). Since the family is a source and user of social capital, family SMEs involve at least three types of social capital: bonding, bridging, and linking (Woolcock, 2001).

\subsection{Bonding}

The first and most important social capital found in FBs is bonding, which refers to relationships between actors that know each other well (family and friends), allowing exchanges of resources based on trust and reciprocity (Lee \& Hallak, 2020). These relationships are reliable, frequent, and horizontal because they develop in an informal and intimate environment within a collective (Payne, Moore, Griffis, \& Autry, 2011; Portes, 1998).

Among the positive aspects is that bonding connects those involved to their primary network and internal resources. In the case of family SMEs, this bonding is based on trust and loyalty, these being some of their internal resources connecting individuals to their primary network, the family. Although this type of relationship is not only limited to the family context, elements such as family history, family values, and the sense of pride and belonging to the surname are difficult elements to imitate (Agger \& Jensen, 2015; Herrero, 2018).

Since within a company, trust, loyalty, a shared vision, and the desire for association generate collectivism, solidarity, and reciprocity, this type of family social capital is probably considered one of the most enduring and influential forms of social capital in general (Arregle, et al., 2007; Uhlaner, et al., 2015). However, from an opposing point of view, very close ties such as those provided by bonding can result in a slow internationalization process because they hinder the identification of new opportunities abroad (Musteen, Francis, \& Datta, 2010).

\subsubsection{Bridging}

Bridging is a type of social capital that describes the company's external relationships; its bonds are weaker and less frequent and informal than in the case of bonding. Those relationships take place between actors from diverse groups or backgrounds (i.e., between a firm and trade organizations), which facilitates the attainment of information that would be otherwise unavailable within an actor's immediate group (i.e., bonding social capital) (Lee \& Hallak, 2020). Although they are also horizontal, they build on norms between individuals with heterogeneous characteristics and interests (Agger \& Jensen, 2015; Salvato \& Melin, 2008).

Among the benefits of these relationships to family SMEs - especially for those with weaker external connections - are the establishment and promotion of trust in peripheral networks, facilitating the establishment of information channels, the identification of opportunities, and the reduction of negotiation and monitoring costs 
required to develop the capacity to "anticipate events" and make the corresponding forecasts (Adler \& Kwon, 2002).

Although bridging is more challenging to develop than bonding in FBs, the resources and advantages of both are ideal for fostering novel ideas, collecting knowledge, and recognizing valuable and useful opportunities that promote the internationalization of the businesses, regardless of their limitations (Widmer, 2006). Despite the benefits this type of capital provides to firms, at least in the context of FBs, this issue remains under-researched (Kontinen \& Ojala, 2011b).

\subsubsection{Linking}

Arregle et al. (2007) state that the time and resource constraints of family SMEs resulting in little investment in social capital can be addressed through public interventions to promote relationships that can contribute to local firms' growth and internationalization. Thus, linking is the third type of social capital and encompasses relationships and networks of trust that entail norms of respect between individuals and people with political, financial, or formal power (Szreter \& Woolcock, 2004).

The linking component of social capital refers to connections made across levels. This form of social capital is vital for governance structures, in which communities interact with regulating bodies and market players. Linking is especially essential for organizations to mobilize political resources and power. The crucial element for good governance is trust, as it enables the exchange of information and improves collaboration for joint decision making (Bakker, Koning, \& Tatenhove, 2019).

The distinctive characteristics of linking are twofold: first, vertical power allows for the establishment of "facilitating" networks in the development of the competitive capacities of local companies acting as an "institutional link"; and second, it gives privileged access for the use of resources, ideas, and information that other conventional links do not provide. This binding power has been crucial in private companies when dealing with government entities; they have carried out a successful internationalization process through cooperation and mutual assistance, showing the effectiveness of these relationships in the era of global markets (Agger \& Jensen, 2015; Siying \& Yiming,
2019). On the other hand, the same vertical power could slow down the deployment of the capacities of the stakeholders if the relationship is unfavorable; for example, the actors could dominate all projects and execute formal sanctions against the stakeholders (Agger \& Jensen, 2015; Sabatini, 2009).

There is evidence that representatives of non-government institutions combine mediating and facilitating abilities to communicate with representatives from different external power sources. It is usual for this type of company to identify with territorial entities, thus establishing privileged relationships (Agger \& Jensen, 2015; Peña \& Sánchez, 2011), but there are no specific works that verify that linking contributes to the internationalization of family SMEs. Therefore, we aim to investigate the topic more deeply in the FB context, since other studies carried out in companies in general (Claessens, Feijen, \& Laeven, 2008) indicate that linking can offer great social and economic benefits in companies promoted by internationalization (Siying \& Yiming, 2019).

Since contextualization is essential in the study of social capital, it is necessary to determine in which contexts these networks become beneficial or detrimental to the internationalization of family SMEs (Evans \& Syrett, 2007).

\subsection{International entrepreneurship}

The study of international entrepreneurship incorporates conventional entrepreneurship and international business. According to Zahra and George (2002), this type of entrepreneurship refers to how companies discover, evaluate, and take advantage of creative opportunities presented beyond their national barriers to achieve competitive advantages in other markets (Baker, Gedajlovic, \& Lubatkin, 2005). Taking advantage of these opportunities will result in superior financial performance, regardless of the internationalizing company's size or age (McDougall \& Oviatt, 2000).

Although entrepreneurship and its dimensions can vary in different businesses, every company that is considered entrepreneurial must exhibit: (i) innovation, which involves exploring, experimenting, and creating; (ii) risk-taking, which is the willingness to commit resources to ideas or projects despite uncertainty, even though failure would probably involve high costs; and (iii) pro-activity, which refers to participation in future 
actions seeking to exploit opportunities in anticipation of upcoming circumstances (Covin \& Wales, 2012).

This composition of the entrepreneurial enterprise allows for answers to be found in complex environments. The combination of resources allows fuller exploitation of opportunities, although this also entails certain risks. Hernández-Linares and LópezFernández (2018) postulate that entrepreneurship helps companies transform their advantages into higher performance levels.

In the case of FBs, an entrepreneurial attitude can be motivated by several factors. First, the long-term nature will allow the company to dedicate the necessary resources to innovation and assume the associated risks, thus promoting an entrepreneurial spirit (Zahra, et al., 2004). Second, family ties can positively affect the recognition of business opportunities. Such associations include the values, beliefs, and goals of the family, its history, and the present social relationships (Hall et al., 2001).

\subsection{Market orientation}

Market orientation (MO) is the organization's intangible resource that allows it to generate and manage information to generate value for its customers, allowing better-oriented strategies to attract new customers and retain existing ones (Hunt \& Lambe, 2000). A company that considers itself to be "market-oriented" is one that values close relationships with its customers, relies on the information provided by the market for strategic decision making, and generates intelligence based on this information (Slater, Mohr, \& Sengupta 2010). For this to be possible, social networks are essential to maximizing the effectiveness of commercial operations, especially in less developed markets (Lau \& Bruton, 2011).

Although MO has been considered to be strictly dependent on the organization, regardless of context, researchers have shown that both the context and the company's export experience and coordination to obtain favorable results abroad are undoubtedly influential (Cadogan, Paul, Salminen, Puumalainen, \& Sundqvist, 2001). From an internationalization perspective, an orientation toward the international market focuses explicitly on the company's activities to gather information about customers' needs abroad, disseminating this information throughout the organization (Frösén, Luoma, Jaakkola, Tikkanen, \& Aspara, 2016).

The relationship between business orientation and international entrepreneurship is built upon the fact that learning functions act as a performance facilitator in international contexts, especially when the company is in its first stages of internationalization. Although the studies are inconclusive as to whether investing in $\mathrm{MO}$ is appropriate for all firms, it is worth pursuing this strategy and examining UNDER what institutional framework it is most effective (Boso, Story, \& Cadogan, 2013). In the case of FBs, MO is considered to be an influential characteristic in their decisions to internationalize (Armario Martin, \& Armario, 2008). Also, we observe higher performance in entrepreneurial firms in developing countries, since the more significant the links established by the companies in their local environment, the greater the advantages and resources will be in terms of generating and disseminating information, and the better they will execute their market-oriented efforts and plans, enhancing their possibilities of success (Acquaah, 2007; Chung, 2012).

Since MO is not a unanimous and generalized concept, we will use the construct "export marketoriented behavior" or "EMO behavior." Cadogan, Diamantopoulos, and Mortanges (1999) used this term based on the generation of company export intelligence, the dissemination of this information for appropriate decision making, and the design and implementation of direct responses to both stakeholders and factors that are exogenous to the company.

Thus a company that considers itself to be "market-oriented" according to the EMO approach will mainly value the current and future needs of export customers and the information coming from the competition and other exogenous factors (regulatory policies, environmental pressures, etc.). By drawing on this information, the company can engage in assertive decision making and obtain greater export intelligence, translating into added value for its stakeholders. From a social capital perspective, the use of social networks is essential for the effectiveness of a company's strategic actions and commercial operations, especially in less developed markets (Lau \& Bruton, 2011).

The EMO approach suggests that better performance by companies in emerging economies derives from the alignment of social networks and EMO practices. Thus, the greater the link between 
the company and its environment, the greater the advantages in terms of the generation and dissemination of information, thus expanding the chances of success abroad (Boso, et al., 2013; Racela, Chaikittisilpa, \& Thoumrungroje, 2007).

\section{Methods}

\section{I Context of the study}

In Mexico, as in many countries around the world, most companies are FBs. SMEs represent 99.8\% of the country's businesses, generating $52 \%$ of the nation's GDP and $72 \%$ of employment (Instituto Nacional de Estadística y Geografía [INEGI], 2019). Despite their notable participation in the Mexican economy, Bolio et al. (2014) explain that their productivity has decreased in various sectors due to multiple factors, such as access to financial services, rigid labor laws, and worker informality.

This article addresses the internationalization of Mexican family SMEs by studying the fishing sector in Campeche. This industry directly generates approximately 350 thousand jobs and indirectly generates more than 2 million jobs nationwide. It accounts for almost 15 thousand jobs in the Yucatan Peninsula (Campeche, Yucatan, and Quintana Roo). Campeche alone accounts for $4.5 \%$ of total Mexican fishing production and occupies $7^{\text {th }}$ place nationally in terms of fishing companies. Another reason to study this sector is that it has experienced low productivity, development, and competitiveness over the last few years, which means that many companies have slowed their international activities without documenting this. This research aims to contribute to the knowledge of the factors that intervene in the promotion or cessation of the internationalization of family businesses in Campeche.

\subsection{Data analysis}

This research uses a fuzzy-set comparative qualitative analysis (fsQCA) to identify which combinations of factors explain the internationalization of family SMEs in emerging economies. We consider this technique to be ideal for studying specific cases such as ours because it allows for a complex analysis with a satisfactory degree of parsimony (Marx, Rihoux, \& Ragin, 2014). QCA includes a mixture of qualitative and quantitative methods. It is a methodology that turns qualitative information into numbers through calibration. Afterward, Boolean minimization is used as a tool to identify conditions in which presence or absence is relevant to produce a particular result (Rihoux \& Marx, 2013). This configurational approach is appropriate for medium-sized samples ( $\mathrm{N}$ between 5 and 50 cases), although it has been applied to larger samples because QCA deals with outliers better than strictly quantitative approaches (Rihoux \& Meur, 2009). It examines the interaction between conditions to produce a result, including all cases. In addition, fsQCA is an approach that addresses asymmetric relationships between the antecedent and the outcome, offering a useful method to tackle the research question - in our case we acknowledge that the factors leading to internationalization may be different to those leading to non-internationalization. This approach has already been applied to the topic of interest (Covin, Eggers, Kraus, Cheng, \& Chang, 2016; Kraus et al., 2016).

Thus, fsQCA does not focus on dependent or independent variables but instead uses conditions that form interacting configurations to find the results. For this reason, its use will allow us to discover causal configurations or conditions from a set of empirical cases that are minimally necessary and/or sufficient for producing an outcome. These interactions will meet the conditions (or contexts) that promote or prevent certain relationships and produce results (Ragin, 2006; Rihoux $\&$ Ragin, 2008). Hence, fsQCA enables the identification of the conditions that lead to the promotion or cessation of family SME internationalization.

Since its introduction in 1987 , the QCA technique has evolved due to many publications in relevant journals that have strengthened its epistemological and methodological foundations by incorporating new versions (Medina, Castillo, Alamos, \& Rihoux, 2017). The mode chosen in this research was fuzzy-set QCA, which is based on fuzzy logic with values ranging from 0 to 1 , where 0 indicates non-membership and 1 indicates full membership of a group. The fuzzy technique was chosen because it is appropriate for variables that take continuous values (Berbegal-Mirabent, Ribeiro-Soriano, \& Sánchez, 2015) and because it is considered a novel method in the management field that provides a better understanding of the optimal configurations of resources (Fiss, 2008; Kraus et al., 2016). 


\subsection{Sample}

Our empirical sample consists of seven family SMEs in the fishing sector. Four companies have internationalized using entry export to the United States, South America, and the European Union, whereas the other three companies have stopped their exports. They are classified as SMEs according to the number of employees they have and the classification provided by the Ministry of Economy and the Ministry of Finance and Public Credit in Mexico, in which a company is small when it has 11 to 50 employees and medium when it has 51 to 200 employees (Table 1). The result to be explained is the occurrence of internationalization (INT) and the non-occurrence of internationalization $(-$ INT).

Having presented the sample, the steps to follow in the QCA methodology are explained below.

\subsection{QCA steps}

The first step was the data collection, which was conducted through a semi-structured interview. The conditions to study were the following: family relationships (bonding), bridging, linking, international entrepreneurship, and market orientation. The second step was the calibration of conditions, which consists of assigning fuzzy values, following the idea of "degrees of belonging" to sets. We used the direct attribution method, which is qualitative and considers the researchers' previous knowledge and experience to position anchors theoretically (Verkuilen, 2005). This is a critical step because the subjective calibration may bias the outcome; thus, the cross-evaluation of experts helps to reduce this risk.

The third step was the analysis of necessary conditions. According to Rihoux and Ragin (2008), QCA is based on the analysis of necessary and sufficient conditions. A condition is necessary if it is present every time the result of interest takes place (although in some cases this condition may be present and the result of interest does not take place). On the other hand, a condition is sufficient to cause a result when this result happens every time this condition is present (although the result may also occur in the absence of this condition).

In this step, both concepts - consistency and coverage - are relevant. Consistency is the extent to which cases sharing similar conditions display the same outcome. In contrast, coverage is the proportion of cases in which both the condition and the result appear (Ragin, 2008). On the other hand, the presence or absence of explanatory conditions is the most critical consideration in any QCA explanation. Presence or absence can be understood in terms of set theory as the inclusion or exclusion of a case in a given set (Rihoux \& Ragin, 2008).

The fourth step of the QCA methodology was Boolean minimization, carried out using the truth table. The truth table shows all the logically possible combinations of existing conditions to reach the result and the number of cases that include these combinations. In the "number" columns, we observe the number of existing cases for each condition configuration. In contrast, in the "raw consistency" column, we observe the cases with the interest rate covered by each condition configuration. After we obtained the necessary parameters in the matrix, we proceeded with Boolean minimization, which has three different formulas: complex, parsimonious, and intermediate. The difference between them lies in how logical remnants are treated. Considering the consistency and coverage parameters of the configurations, the parsimonious solution was chosen to obtain the results of this analysis. According to Berbegal-Mirabent (2017), the parsimonious solution automatically minimizes the number of possible conditions containing the prime implicants. The logical remnants that meet the needs criteria exclude those that do not fulfill them.

The "raw coverage" and "unique coverage" indicators are distinguished as part of this technique, estimating the percentage of cases that contain the resulting configurations to produce the desired result. Another indicator that adds to the parsimonious solution's interpretation is the "consistency," which explains the proportion of cases that have both the condition and the result within the total number of cases, ultimately showing the percentage of coverage that has the solution, unlike the other two solutions. Based on this explanation, we present the results of our empirical study in the following section.

\section{Results}

\section{I Data collection and calibration}

We used a semi-structured interview for data collection purposes. This interview consisted of 44 questions, previously reviewed and approved by experts in the field, to be answered by owners and managers of the seven family SMEs (Appendix 1). The interviewer recorded 
Table 1

Sample and variables

\begin{tabular}{|c|c|c|c|c|c|}
\hline Case & Company & Size & Current status & Variables studied & Nomenclature \\
\hline 1 & Marganzo & Small & Exporting & Family relationships & Bnd \\
\hline 2 & Conpesmar & Small & Exporting & Bridging & $\mathrm{Brg}$ \\
\hline 3 & Mexusa & Medium & Exporting & Linking & Link \\
\hline 4 & Dos Burros & Medium & Exporting & $\begin{array}{c}\text { International } \\
\text { Entrepreneurship }\end{array}$ & Entr \\
\hline 5 & Romellón & Medium & Not exporting & Market orientation & Mkt \\
\hline 6 & Marquez & Medium & Not exporting & & \\
\hline 7 & Oryon & Small & Not exporting & & \\
\hline
\end{tabular}

Table 2

\section{Calibration data matrix for six-value fuzzy set}

\begin{tabular}{|c|c|c|c|c|c|c|}
\hline Cases & Bnd & $\mathrm{Brg}$ & Link & Entr & Mkt & INT \\
\hline 1 & 0.9 & 0.9 & 1 & 0.9 & 0.9 & 0.9 \\
\hline 2 & 0.6 & 1 & 0.6 & 1 & 1 & 0.9 \\
\hline 3 & 0.9 & 1 & 0.6 & 0.9 & 0.9 & 0.6 \\
\hline 4 & 0.4 & 1 & 0.9 & 0.6 & 0.9 & 1 \\
\hline 5 & 0.4 & 0.6 & 0.1 & 0.6 & 0.6 & 0 \\
\hline 6 & 1 & 0.6 & 0.1 & 0.4 & 0.6 & 0 \\
\hline 7 & 0.9 & 0.1 & 0.1 & 0.1 & 0 & 0 \\
\hline
\end{tabular}

Table 3

\section{Needs analysis}

\begin{tabular}{cccccc}
\hline Result & \multicolumn{2}{c}{ Internationalization $($ INT) } & & \multicolumn{2}{c}{ Non-Internationalization $(\sim$ INT) } \\
\cline { 1 - 2 } \cline { 5 - 6 } Conditions & Consistency & Coverage & & Consistency & 0.568627 \\
Bnd & 0.735294 & 0.490196 & & $\mathbf{0 . 8 0 5 5 5 6}$ & 0.526316 \\
- Bnd & 0.352941 & 0.631579 & 0.277778 & 0.365385 \\
Brg & $\mathbf{1 . 0 0 0 0 0 0}$ & 0.653846 & 0.527778 & 1.000000 \\
-Brg & 0.029412 & 0.055556 & 0.500000 & 0.264706 \\
Link & $\mathbf{0 . 8 8 2 3 5 3}$ & 0.882353 & 0.250000 & 0.888889 \\
- Link & 0.264706 & 0.250000 & & $\mathbf{0 . 8 8 8 8 8 9}$ & 0.377778 \\
Entr & $\mathbf{0 . 8 8 2 3 5 3}$ & 0.666667 & 0.472222 & 0.840000 \\
-Entr & 0.176471 & 0.240000 & 0.583333 & 0.367347 \\
Mkt & $\mathbf{0 . 9 7 0 5 8 8}$ & 0.673469 & 0.500000 & 0.952381 \\
$\sim$ Mkt & 0.088235 & 0.142857 & 0.555556 & \\
\hline
\end{tabular}

their opinions. We sorted the 44 questions into five groups based on the variables they cover. Next, the answers were calibrated using the previously described six-value fuzzy set: [1] totally belonging to the variable group; [0.9] mostly, but not totally, within the group; [0.6] more in than out of the group, [0.4] more out than in the group, [0.1] mostly out of the group, and [0] not belonging to the group (Table 2).

\section{2 fsQCA data analysis}

An analysis of the necessary conditions for the occurrence or non-occurrence of family SME internationalization was made using fuzzy-set QCA. The values obtained for INT were used for the analysis of the required conditions for internationalization. A sufficiency threshold of 0.80 to 
1 was valid for internationalization. This threshold was also taken as accurate for the needs analysis of $\sim$ INT (Table 3).

Based on the previous coverage and consistency values, we estimated that bridging, linking, international entrepreneurship, and market orientation all have the necessary explanatory conditions for the internationalization of the family SMEs. The conditions profiled as necessary for the cessation of internationalization are displayed in Table 3. The needs analysis for - INT indicates that Bnd, the presence of bonding in the FB, and $\sim$ Link, a lack of institutional links for family SMEs, are necessary conditions for the non-occurrence of internationalization.

Next, we show in Table 4 all the possible combinations of the existing conditions and the number of cases that include these combinations for the result studied. After removing the rows with no empirical observations, the truth table is as follows:

As already explained, the "number" column shows the number of cases in which the combination of variables is met. Thus, 3 and 1 correspond to the number of exporting companies, which totals four. In the INT column, 1 indicates a positive outcome for internationalization. The other combinations have 0 because the minimum accepted consistency level is 0.80 , meaning they do not have a positive outcome for INT.
The "raw consistency" column indicates that only one of the four companies has a consistency close to 1 , which means that this is the only case obtaining this result. Dos Burros is the only company that uses its resources and capabilities to take advantage of its relationship with its stakeholders and public institutions, shows international entrepreneurship, and displays a market orientation to internationalize. The other three companies (Marganzo, Conpesmar, and Mexusa) have the same result for internationalization but following a different path, through a different configuration of variables. These three companies add the family component of bonding to the configuration used by Dos Burros, as can be seen in the truth table.

The next step was the Boolean minimization. This simplifying assumption process provided the following result: linking is a necessary and sufficient condition to cause internationalization in FBs. This result is displayed in Table 5, where $\bullet$ indicates that the presence of the condition is necessary, $\bigcirc$ indicates that the absence of the condition is necessary, and nothing suggests this condition is irrelevant.

These solutions show that the complex and intermediate solutions could equally explain the result for the internationalization of family SMEs with the same

Table 4

\section{Truth Table for INT}

\begin{tabular}{cccccccccc}
\hline Bnd & Brg & Link & Entr & Mkt & Number & INT & $\begin{array}{c}\text { Raw } \\
\text { Consist }\end{array}$ & $\begin{array}{c}\text { PRI } \\
\text { Consist }\end{array}$ & $\begin{array}{c}\text { SYM } \\
\text { Consist }\end{array}$ \\
\hline 1 & 1 & 1 & 1 & 1 & 3 & 1 & 0.9259 & 0.9047 & 0.9047 \\
0 & 1 & 1 & 1 & 1 & 1 & 1 & 0.9230 & 0.9000 & 0.9000 \\
0 & 1 & 0 & 1 & 1 & 1 & 0 & 0.5000 & 0.4000 & 0.4000 \\
1 & 1 & 0 & 0 & 1 & 1 & 0 & 0.1666 & 0.0909 & 0.0909 \\
1 & 0 & 0 & 0 & 0 & 1 & 0 & 0.0000 & 0.0000 & 0.0000 \\
\hline
\end{tabular}

Table 5

\section{QCA solutions for INT}

\begin{tabular}{|c|c|c|c|c|c|c|c|c|c|c|}
\hline \multirow{2}{*}{ Solution } & \multicolumn{5}{|c|}{ Configurations } & \multirow{2}{*}{$\begin{array}{c}\text { Raw } \\
\text { Coverage }\end{array}$} & \multirow{2}{*}{$\begin{array}{c}\text { Unique } \\
\text { Coverage }\end{array}$} & \multirow{2}{*}{ Consistency } & \multirow{2}{*}{$\begin{array}{l}\text { Solution } \\
\text { Coverage }\end{array}$} & \multirow{2}{*}{$\begin{array}{c}\text { Solution } \\
\text { Consistency } \\
\end{array}$} \\
\hline & Bnd & $B r g$ & Link & Entr & $M k t$ & & & & & \\
\hline $\begin{array}{l}\text { Complex } \\
\text { Solution }\end{array}$ & & $\bullet$ & $\bullet$ & $\bullet$ & $\bullet$ & 0.794 & 0.794 & 0.931 & 0.794 & 0.931 \\
\hline $\begin{array}{c}\text { Parsimonious } \\
\text { Solution }\end{array}$ & & & $\bullet$ & & & 0.882 & 0.882 & 0.882 & 0.8823 & 0.882 \\
\hline $\begin{array}{c}\text { Intermediate } \\
\text { Solution }\end{array}$ & & $\bullet$ & $\bullet$ & $\bullet$ & $\bullet$ & 0.794 & 0.794 & 0.931 & 0.7941 & 0.931 \\
\hline
\end{tabular}


configurations. This does not occur with the parsimonious solution. The grouped conditions are considered INUS (insufficient but necessary), which means that they are part of a configuration that produces internationalization, but only when all the conditions are present. However, the parsimonious solution shows that linking is an independent condition that leads to internationalization.

It is estimated that $88 \%$ of cases with the raw coverage and unique coverage configuration produce the outcome. This percentage of cases only requires linking for internationalization to happen. The consistency indicator explains the proportion of cases with both the condition and the result within the total number of cases; this is the proportion of cases that internationalize due to the support provided and the relational links between public institutions and the FB.

According to Table 5, the parsimonious solution has the highest coverage of cases with the result of interest $(88 \%)$ and consistency equal to $88 \%$, unlike the complex solution and the intermediate solution. The parsimonious solution covers most exporting companies: Dos Burros, Marganzo, Conpesmar, and Mexusa.

The truth table for $\sim$ INT is shown in Table 6 below. For the three companies that do not currently internationalize, two cases can be explained with sufficient robustness (raw consistency greater than 0.80 ) while the third has consistency below the threshold.

Boolean minimization leads to three solutions for the cessation of internationalization, as displayed in Table 7 below.

The parsimonious solution is chosen as a benchmark for the results. It shows two configurations with equifinality for the absence of internationalization: (i) absence of international entrepreneurship, and (ii) family presence and the absence of institutional linking. Both of these lead FBs to stop exporting. Again, $\bullet$ indicates that the presence of the condition is necessary, $\bigcirc$ indicates that the lack of the condition is necessary, and nothing indicates that this condition is irrelevant.

Unlike the complex and intermediate solutions, this solution shows greater robustness and consistency because it encompasses more cases with a result of interest (77\%) and indicates how many cases are covered by its two configurations. Thus, $80 \%$ contain this result, unlike the other two solutions, which provides more reliability and certainty when evaluating the solutions as a whole.

Analyzing the combinations of variables provides direct evidence by combining raw coverage and unique coverage. Thus, - Entr explains that $58 \%$ of the cases

Table 6

\section{Truth table for $\sim$ INT}

\begin{tabular}{cccccccccc}
\hline Bnd & Brg & Link & Entr & Mkt & Number & INT & $\begin{array}{c}\text { Raw } \\
\text { Consist }\end{array}$ & $\begin{array}{c}\text { PRI } \\
\text { Consist }\end{array}$ & $\begin{array}{c}\text { SYM } \\
\text { Consist }\end{array}$ \\
\hline 1 & 0 & 0 & 0 & 0 & 1 & 1 & 1.0000 & 1.0000 & 1.0000 \\
1 & 1 & 0 & 0 & 1 & 1 & 1 & 0.9166 & 0.9090 & 0.9090 \\
0 & 1 & 0 & 1 & 1 & 1 & 0 & 0.6666 & 0.6000 & 0.6000 \\
0 & 1 & 1 & 1 & 1 & 1 & 0 & 0.3076 & 0.1000 & 0.1000 \\
1 & 0 & 1 & 1 & 1 & 3 & 0 & 0.2962 & 0.0952 & 0.0952 \\
\hline
\end{tabular}

Table 7

\section{QCA solutions for $\sim$ INT}

\begin{tabular}{|c|c|c|c|c|c|c|c|c|c|c|}
\hline \multirow{2}{*}{ Solution } & \multicolumn{5}{|c|}{ Configurations } & \multirow{2}{*}{$\begin{array}{c}\text { Raw } \\
\text { Coverage }\end{array}$} & \multirow{2}{*}{$\begin{array}{c}\text { Unique } \\
\text { Coverage }\end{array}$} & \multirow{2}{*}{ Consistency } & \multirow{2}{*}{$\begin{array}{l}\text { Solution } \\
\text { Coverage }\end{array}$} & \multirow{2}{*}{$\begin{array}{c}\text { Solution } \\
\text { Consistency }\end{array}$} \\
\hline & Bnd & $\mathrm{Brg}$ & Link & Entr & Mkt & & & & & \\
\hline \multirow[t]{2}{*}{ Complex Solution } & $\bullet$ & o & o & o & o & 0.472 & 0.250 & 1.000 & 0.555 & 0.952 \\
\hline & $\bullet$ & $\bullet$ & ० & ० & $\bullet$ & 0.305 & 0.083 & 0.916 & & \\
\hline Parsimonious & & & & ० & & 0.583 & 0.027 & 0.840 & 0.777 & 0.800 \\
\hline Solution & $\bullet$ & & ○ & & & 0.750 & 0.194 & 0.870 & & \\
\hline Intermediate & $\bullet$ & ○ & ○ & ० & ○ & 0.472 & 0.250 & 1.000 & 0.555 & 0.952 \\
\hline Solution & $\bullet$ & $\bullet$ & $\circ$ & ० & $\bullet$ & 0.305 & 0.083 & 0.916 & & \\
\hline
\end{tabular}


no longer export due to a lack of international interest. Unique coverage shows that only $2 \%$ of that $58 \%$ do not export exclusively for this reason. The consistency indicator shows that $84 \%$ of cases do not internationalize due to a lack of international entrepreneurship. These cases are Marquez and Oryon.

The Bnd* - Link configuration causes the -INT outcome for the second configuration with equifinality. This combination explains $87 \%$ of the cases, and $19 \%$ can be defined by this configuration alone (single coverage). Consistency indicates that $87 \%$ of the cases internationalize in this way. These cases are Marquez and Oryon. The last $13 \%$ is due to the third case - Romellón - which does not currently export.

As can be seen in the truth table, this company does not have a 1 in the "number" column because its raw consistency is below the established threshold (0.80 to 1$)$. It is a particular case because, although it is a second-generation $\mathrm{FB}$, it only has a small amount of family involvement. This explains its uncommon behavior and the 0 in the bonding column. Despite this, its linking is the same as in other companies that do not export. This company shows similar institutional support and relationships as other companies. It has an active international entrepreneurial attitude (exporting to several countries for many years). It is owned by a family, although the family's involvement is low, and it does not have outstanding institutional links. This company has a consistency of 0.6667 , and the parsimonious solution Bnd*_Link explains this.

\section{Discussion}

The propositions that we present based on the literature review and the empirical study developed allow us to identify the emerging theoretical contributions using an inductive approach, in order to advance the knowledge in this field. This was achieved by: (i) examining littlestudied variables concerning the internationalization of FBs, as is the case of linking and market orientation, and their relationship with networks and internationalization; (ii) showing the existence of a more optimal and novel way for family SMEs to achieve success in internationalization; (iii) studying FBs from a relational perspective and internationalization in more advanced stages of creation and commercial development; (iv) addressing the need to deepen the research on the internationalization of SMEs in emerging economies, especially in Mexico, where research on the internationalization of FBs is scarce, and (v) addressing the need to understand the decline of the economic sector examined, which is so crucial for the country.

Regarding the configurations resulting from the fsQCA, we emphasize that the linking type of social capital provides a sufficient condition for companies to expand abroad. Its unique and binding relational power with associations, governmental entities, and political and/or financial institutions provides communication, knowledge resources, and economic access, making companies competitive. We summarize this in the following proposition:

a) Proposition 1. Linking is a sufficient relational component for the internationalization of family SMEs in emerging market contexts, thanks to its binding and beneficial aspect and institutional power to make companies competitive.

Given that $100 \%$ of the FBs currently exporting have used this link to make use of resources, it is common for family SMEs to establish privileged relationships with local political institutions (Peña \& Sánchez, 2011). This link in itself is a value generator, which allows them to open up, expand, and strengthen their presence abroad based on these relationships (Agger $\&$ Jensen, 2015).

As an example of these institutional links established by the companies - according to the information provided by them - Marganzo received subsidies from the federal government (Ministry of Economic Development) of at least $60 \%$ of the start-up costs of its manufacturing plant. Similarly, Conpesmar received prospective clients through business agendas established by the ProMexico Association. Finally, Mexusa benefited from a subsidy from the National Entrepreneurs Institute to finance machinery and training. The federal government (SAGARPA) subsidizes a percentage of these four companies' annual fuel costs.

The fsQCA identified two routes for the cessation of internationalization ( INT). This leads to the following proposition:

b) Proposition 2. A lack of international entrepreneurship and the family's presence and involvement in the company, together with an absence of institutional links, are responsible for family SMEs ceasing their internationalization.

This proposal shows the relationships that influence the cessation of the companies' internationalization, for Marquéz, Oryon, and, with less consistency, 
Romellón. After analyzing the results, we conclude that Marquez and Oryon ceased exporting due to a lack of international entrepreneurship. Although this result is concise, the companies' level of coverage is different due to their different family backgrounds and contexts. Thus, although Marquez is not currently exporting due to a lack of incentives in international markets, other reasons have also influenced this decision. The company was founded in 1960 and started its international operations in 1970, exporting pink shrimp and fish to the United States and South America. In 2008, its operations abroad ceased due to several problems: product supply, unfortunate public policies that harmed the shrimp industry (which caused the company's current risk aversion), and a lack of interest in entering new international markets.

Unlike Marquéz, which has exported for decades, Oryon suffered considerable economic losses in its first attempt to export. This happened due to a lack of information, language issues, and a lack of experience in the international arena. Although they are currently in recovery, they show a notable lack of international entrepreneurial initiative.

In this case, our results are in line with those of Lumpkin and Dess (1996) and Sciascia, Mazzola, Astrachan, and Pieper (2012), since international entrepreneurship has been affected by the internal factors already mentioned that direct the companies to continue operating only locally. Some of the external factors that influence both companies are the environmental uncertainty, the instability in the operations derived from problems with public policies, and the lack of support from the federal and state governments (Ramírez, 2015).

These two companies ceased exporting because they lost their desire to be proactive, to innovate, to take risks abroad, and to operate internationally. They have chosen to protect their resources by operating at the national level to guarantee the control and continuity of the FB. This is a characteristic trend of FBs (Arregle et al., 2017).

The other necessary condition is the presence of family involvement in management. The family's influence can be of several types, causing the heterogeneity of results in the investigations into the internationalization of FBs. It is important to identify the different roles that the family plays within the company (Arregle,
Naldi, Nordqvist, \& Hitt, 2012; Chrisman, Chua, \& Sharma, 2005).

Several different types of FB can be identified: companies directed by a family; companies that the family owns but where it does not intervene in the control and management; and companies that have the family as both owner and manager at the same time. The latter type is the one found in Marquez, Oryon, and Romellón. The family's presence in the ownership and management of these three cases is the most inconvenient factor for the exploitation of international markets. A high concentration of family ownership, family involvement in management without external support, centralized decision making, and a strong desire for continuity, means that the power the family has in the firms' strategic development is discretional, resulting in an impediment to internationalization (Gomez-Mejial, Makri, \& Kintana, 2010; Sciascia et al., 2012). In addition to these limitations, these companies do not have institutional relational links (linking) that can serve as support or links for accessing resources, so these companies lack resources and capabilities of all kinds.

From a relational perspective, the very nature of a FB tends to protect the company's social-emotional wealth, limiting internationalization, although there are positive relational links for the FB. The linking effects of internationalization and the internal bonding link generate a strong tendency to protect the family's socio-emotional wealth more than the economic wealth, which results in a lower interest in internationalization (Arregle et al., 2012; Kontinen \& Ojala, 2012a).

\section{Conclusion}

Our research provides fresh input to the long-standing debate on the need to identify the configurations of FBs to improve their performance and their internationalization processes (Basco, 2013; Sciascia et al., 2012). This research primarily focuses on companies in emerging market contexts such as Mexico, where research on the internationalization of FBs is still very scarce. We thus respond to the demands for more in-depth research on the internationalization of SMEs in emerging economies (Genc, Dayan, \& Genc, 2019; Kiss, et al., 2012).

To carry out our study, we covered a mix of innovative variables, including international entrepreneurship, social 
capital in its three modalities (bonding, bridging, and linking), and export market orientation, to understand how they influence the promotion or cessation of internationalization. By examining these different organizational configurations, we showed that there is more than one optimal way for FBs to achieve successful internationalization results.

Our empirical findings align with the theory of social capital (Pinho \& Prange, 2016; Tasavori et al., 2018). Our results reveal that linking, a social capital with vertical power, is sufficient to promote the internationalization of family businesses in an emerging market context, through an endowment of resources and information that do not offer conventional links, according to the contributions of Agger and Jensen (2015), Peña and Sánchez (2011), and Sabatini (2009).

Our study of the relationships between companies and government institutions through linking contributes to providing new knowledge, by recognizing that the external institutional environment influences companies' international strategies, both in choosing their mode of entry and investment decisions. These results support the findings of Cuervo-Cazurra and Ramamurti (2013) and Cuervo-Cazurra, Gaur, and Singh (2019). In Mexico, institutions act as a source of competitive advantage for some companies, but not for all, as seen with the companies studied here. The stronger the linkage, the greater the institutional support and strategic advantages for the company.

Likewise, in the Mexican context, we show that bonding, which is made up of horizontal internal ties and represents the family, together with a lack of institutional relationships, is a burden when making decisions and taking risks in the international arena. Mexican FBs are less likely to become international than their non-family counterparts unless they establish external relational ties with some type of institutional power, especially the government. Since our findings provide two routes to the cessation of internationalization, we also offer a view of the entrepreneurial spirit of FBs, showing that it is indeed crucial to expand into other markets abroad (Casillas, et al. 2007; Kontinen \& Ojala, 2011). A lack of this element alone is sufficient enough to have a direct impact on the international operations of companies. We also show that the companies that ceased to export were partly influenced by internal and external factors that affected their entrepreneurial spirit, as claimed by Sciascia et al. (2012).
Our research supports outside relationships and promoting external links with public entities such as government institutions. Otherwise, companies will be limited to their own resources, experience, and knowledge. This result is consistent with the findings of Kraus et al. (2016) and Siying and Yiming (2019). Incorporating external personnel into the FB may be essential because all resource types are finite. Following Lora and Ramírez (2013), a change in regulations, planning, and adequate legislation is necessary, along with the generation of productive projects and nondiscriminatory public support, as well as reform of the legal framework for fishing, to safeguard species and avoid overfishing.

\section{Managerial Implications and Limitations of the Study}

\section{I Managerial implications}

This work also seeks to provide practical contributions for family entrepreneurs in the fishing sector and broaden their understanding of the phenomenon of internationalization. Although international and national entities recognize Mexican fishing as a critical instrument for the development of Mexican coastal localities (i.e., Campeche), the truth is that the sector's public policies seem to underestimate the potential to develop the industry. They lack concrete lines to promote and develop individuals, groups, and organizations to achieve their economic and social development (Lora \& Ramírez, 2013). The exporting FBs have sought and encouraged linking with relevant public institutions, using this as a facilitator of communication, the use of resources, the development of competitive capabilities, and access to useful information provided exclusively by external power sources. Regarding the managerial implications, it is advisable to approach national and state institutions and public or private organizations that support business internationalization. Some of these organizations include the Secretaría de Economía and ProMéxico, among others.

Regarding the family's presence and involvement, we emphasize incorporating non-family shareholders into the FB to provide economic resources and financial autonomy to the company without government support while enriching decision making, decentralizing it, and 
moderating the family's influence concerning international operations. Second, we advise moderating the family's involvement by including external personnel with previous internationalization experience in managerial positions to contribute to the FB's international operations. The specific literature supports these considerations since having external personnel in FBs adds experience, objectivity, different perspectives, information, and new social networks that the family itself does not possess (González-Cruz \& Cruz-Ros, 2016).

Thus, our results emphasize the moderation of family participation, through external personnel in the management area. Congeladora Marquez shows fear of exposure due to the uncertain productivity of the sector. Oryon has had problems with its performance, due to it lacking resources, language skills, knowledge of business management, and market research, which caused it to fail in its first steps towards internationalization. Therefore, we believe that taking on external personnel with previous experience in internationalization would be useful in this context since external personnel provide knowledge and experience and reduce risk aversion (Arregle et al., 2007; Dar \& Mishra, 2020; Sirmon, Arregle, Hitt, \& Webb, 2008). These academic findings apply to this context because companies such as Conpesmar and Marganzo have succeeded with a mixture of family and non-family personnel specializing in exports in decisive positions, allowing them to use this knowledge and experience. They have developed a number of processes, including reforms in the production plant, international certification, visiting international fairs, and search for new customers.

\section{$7 \cdot 2$ Limitations of the study}

Finally, our research is not without its limitations. First, we only conducted this research in the emerging economy of Mexico, so its generalization is restricted. Future research could improve our findings by using the same mix of variables but by collecting data in developed countries. Second, expanding the sample could yield even more interesting results. Since this study addresses the international context, it would be interesting to test this mix of variables in the national context, using market orientation without the export approach and entrepreneurship without being international. Finally, we suggest collecting data from other types of family SMEs to test our findings in different productive sectors.

\section{Reference}

Abdellatif, M., Amann, B., \& Jaussaud, J. (2010). Family versus non-family business: A comparison of international strategies. Journal of Family Business Strategy, 1(2), 108-116.

Acquaah, M. (2007). Managerial social capital, strategic orientation, and organizational performance in an emerging economy. Strategic Management Journal, 28(12), 1235-1255.

Adler, P., \& Kwon, S. (2002). Social capital: Prospects for a new concept. Academy of Management Review, 27(1), 17-40.

Agger, A., \& Jensen, J. (2015). Area-based initiative: And their work in bonding bridging and linking social capital. European Planning Studies, 23(10), 2045-2061.

Ahlstrom, D., Bruton, G., \& Yeh, K. (2007). Venture capital in china: Past, present, and future. Asia Pacific Journal of Management, 24(3), 247-268.

Armario, J., Martin, D., \& Armario, E. (2008). Market orientation and internationalization in small and mediumsized enterprises. Journal of Small Business Management, 46(4), 485-511.

Arregle, J., Duran, P., Hitt, M., \& Essen, M. van, (2017). Why is family firms' internationalization unique? A meta-analysis. Entrepreneurship Theory and Practice, 41(5), 801-831.

Arregle, J., Naldi, L., Nordqvist, M., \& Hitt, M. (2012). Internationalization of family-controlled firms: A study of the effects of external involvement in governance. Entrepreneurship: Theory and Practice, 36(6), 1115-1143. https://doi.org/10.1111/j.1540-6520.2012.00541.x

Arregle, K., Hitt, M., Sirmon, D., \& Very, P. (2007). The development of organizational social capital: Attributes of family firms. Journal of Management Studies, 44(1), 73-95.

Baker, T., Gedajlovic, E., \& Lubatkin, M. (2005). A framework for comparing entrepreneurship processes across nations. Journal of International Business Studies, 36(5), 492-504.

Bakker, Y. W., Koning, J., \& Tatenhove, J. (2019). Resilience and social capital: The engagement of fisheries 
communities in marine spatial planning. Marine Policy, 99, 132-139.

Basco, R. (2013). The Family's effect on family firm performance: A model testing the demographic and essence approaches. Journal of Family Business Strategy, 4(1), 42-66.

Berbegal-Mirabent, J. (2017, October). Fundamentals of Qualitative Comparative Analysis (QCA). Course on QCA methodology, Seville, Andalucia, Spain, Course Num.1

Berbegal-Mirabent, J., Ribeiro-Soriano, D., \& Sánchez, J. (2015). Can a magic recipe foster university spin-off creation? Journal of Business Research, 68(11), 2272-2278.

Bolio, E., Remes, J., Lajous, T., Manyika, J., Rossé, M., \& Ramirez, E. (March, 2014). A tale of two Mexicos: Growth and prosperity in a two-speed economy. McKinsey global institute. Retrieved from https://www.mckinsey. $\mathrm{com} /$ featured-insights/americas/a-tale-of-two-mexicos\#

Boso, N., Story, V. M., \& Cadogan, J. (2013). Entrepreneurial orientation, market orientation, network ties, and performance: Study of entrepreneurial firms in a developing economy. Journal of Business Venturing, 28(6), 708-727.

Bruton, G., Ahlstrom, D., \& Obloj, K. (2008). Entrepreneurship in emerging economies: Where are we today and where should the research go in the future. Entrepreneurship Theory and Practice, 32(1), 1-14.

Cadogan, J., Paul, N., Salminen, R., Puumalainen, K., \& Sundqvist, S. (2001). Key antecedents to "export" market-oriented behaviors: A cross-national empirical examination. International Journal of Research in Marketing, 18(3), 261-282.

Cadogan, J., Diamantopoulos, A., \& Mortanges, C. (1999). A measure of export market orientation: Scale development and cross-cultural. Journal of International Business Studies, 30(4), 689-707.

Calabrò, A., \& Mussolino, D. (2013). How do boards of directors contribute to family SME export intensity? The role of formal and informal governance mechanisms. Journal of Management and Governance, 17(2), 363-403.
Carney, M., Essen, M., Gedajlovic, E., \& Huegens, P. (2015). What do we know about the private family firm? A meta-analytic review. Entrepreneurship Theory and Practice, 39(3), 513-544.

Casillas. J., Acedo. F., \& Moreno. A. (2007). International Entrepreneurship in Family Businesses. Spain: Edward Elgar Publishing Limited.

Cheng, C., Chang, M., \& Chu, S. (2013). Configural paths of successful product innovation. Journal of Business Research, 66(12), 2561-2573.

Chung, H. (2012). Export market orientation, managerial ties, and performance. International Marketing Review, 29(4), 403-423.

Chrisman, J., Chua, J., \& Sharma, P. (2005). Trends and directions in the development of strategic management theory of the family firm. Entrepreneurship Theory and Practice, 29(5), 555-575.

Claessens, S., Feijen, E., \& Laeven L. (2008). Political connections and preferential access to finance: The role of campaign contributions. Journal of Financial Economics, 88(3), 554-580.

Claver, E., Rienda, L., \& Quer, D. (2008). Family firms' risk perception: Empirical evidence on the internationalization process. Journal of Small Business and Enterprise Development, 15(3), 457-471.

Coviello, N. (2006). The network dynamics of international new ventures. Journal of International Business Studies, 37(5), 713-731.

Covin, J., Eggers, F., Kraus, S., Cheng, C., \& Chang, $M$ (2016). Marketing-related resources and radical innovativeness in family and non-family firms: A configurational approach. Journal of Business Research, 69(12), 5620-5627.

Covin, J. G., \& Wales, W. J. (2012). The Measurement of entrepreneurial orientation. Entrepreneurship Theory and Practice, 36(4), 677-702.

Crick, D., \& Spence, M. (2005). The internationalisation of 'high performing' UK high-tech SMEs: A study of planned and unplanned strategies. International Business Review, 14(2), 167-185. 
Cuervo-Cazurra, A., \& Ramamurti, R. (2013). Understanding Multinationals from Emerging Markets. Boston: Northeastern University.

Cuervo-Cazurra, A., Gaur, A., \& Singh, D. (2019). Promarket institutions and global strategy: The pendulum of pro-market reforms and reversals. Journal of International Business Studies, 50(4), 598-632.

Dar, I. A., \& Mishra, M. (2020). Dimensional impact of social capital on financial performance of SMEs. Journal of Entrepreneurship, 29(1), 38-52.

Erdogan, I., Rondi, E., \& De Massis, A. (2020). Managing the tradition and innovation paradox in family firms: A family imprinting perspective. Entrepreneurship Theory and Practice, 44(1), 20-54.

Evans, M., \& Syrett, S. (2007). Generating social capital? The social economy and local economic development. European Urban and Regional Studies, 14(1), 55-74.

Essen, M. Carney, M., \& Gedajlovic, E. (2015). How does family control influence firm strategy and performance? A meta-analysis of us publicly listed firms. Corporate Governance: An International Review, 23(1), 3-24.

Fiss, P. C. (2008). Configurations of strategy, structure, and environment: A fuzzy-set analysis of high technology firms (Work Paper n. 2008-04-21). Retrieved from http://web. mit.edu/bpsmini/2008/Peer-C-Fiss.pdf

Frösén, J., Luoma, J., Jaakkola, M., Tikkanen, H., \& Aspara, J. (2016). What counts versus what can be counted: The complex interplay of market orientation and marketing performance measurement. Journal of Marketing, 80(3), 60-78.

Gamage, S., Prasanna, R., Jayasundara, J., Ekanayake, E., Rajapakshe, P., Gaknj, A., ... Nedelea, A. (2020). Social capital and SME: A systematic literature review and research directions. Ecoforum, 9(3), 1-12.

Genc, E., Dayan, M., \& Genc, O. (2019). The impact of SME internationalization on innovation: The mediating role of market and entrepreneurial orientation. Industrial Marketing Management, 82, 253-264.

Gittins, T., Lang, R., \& Sass, M. (2015). The effect of return migration driven social capital on SME internationalisation: A comparative case study of it sector entrepreneurs in Central and Eastern Europe. Review of Managerial Science, 9(2), 385-409.

Gomez-Mejia, L., Makri, M., \& Kintana, M. (2010). Diversification decisions in family-controlled Firms. Journal of Management Studies, 47(2), 223-252.

González-Cruz, T., \& Cruz-Ros, S. (2016). When does family involvement produce superior performance in SME family business? Journal of Business Research, 69(4), 1452-1457.

Global Biotech Consulting Group. (2012). Producción del Pulpo en México. Retrieved from http://www.gbcbiotech. com/genomicaypesca/especies/moluscos/pulpo.html

Hall, A., Melin, L., \& Nordqvist, M. (2001). Entrepreneurship as radical change in the family business: Exploring the role of cultural patterns. Family Business Review, 14(3), 193-208.

Hennart, J., Majocchi, A., \& Forlani, E. (2019). The myth of the stay-at-home family firm: how family-managed SMEs can overcome their internationalization limitations. Journal of International Business Studies, 50, 758-782.

Hernández, A., Mendoza, J., \& Salazar, B. (2015). Exploring family-owned businesses in the state of hidalgo, Mexico. European Scientific Journal, 11(19), 125-146.

Hernández-Linares, R., \& López-Fernández, M. C. (2018). Entrepreneurial orientation and the family firm: Mapping the field and tracing a path for future research. Family Business Review, 31(3), 318-351.

Herrero, I. (2018). How familial is family social capital? Analyzing bonding social capital in family and non-family firms. Family Business Review, 31(4), 441-459.

Hofstede, G., Hofstede, G., \& Minkov, M. (2010). Cultures and Organizations: Software of the Mind. New York: McGraw-Hill, Ed.

Hunt, S., \& Lambe, C. (2000). Marketing's contribution to business strategy: Market orientation, relationship marketing, and resource-advantage theory. International Journal of Management Reviews, 2(1), 17-43. 
Ibeh, K., \& Kasem, L. (2011). The network perspective and the internationalization of small and medium-sized software firms from Syria. Industrial Marketing Management, 40(3), 358-367.

Instituto Nacional de Estadística y Geografía. (2019). Censos economicos 2019. México: Autor. Retrieved from https://www.inegi.org.mx/programas/ce/2019/

Johanson, J., \& Vahlne, J. (1977). The internationalization process of the firm: A model of knowledge development and increasing foreign commitments. Journal of International Business Studies, 8(2), 93-98.

Johanson, J., \& Vahlne, J. (2009). The Uppsala internationalization process model revisited: From liability of foreignness to liability of outsidership. Journal of International Business Studies, 40(9), 1411-1431.

Kiss, A., Danis, W., \& Cavusgil, S. (2012). International entrepreneurship research in emerging economies: $\mathrm{A}$ critical review and research agenda. Journal of Business Venturing, 27(2), 266-290.

Kontinen, T., \& Ojala, A. (2011a). Network ties in the international opportunity recognition of family SMEs. International Business Review, 20(4), 440-453.

Kontinen, T., \& Ojala, A. (2011b). Social capital in relation to the foreign market entry and post-entry operations of family SMEs. Journal of International Entrepreneurship, 9(2), 133-151.

Kraus, S., Mensching, H., Calabrò, A., Cheng, C. F., \& Filser, M. (2016). Family firm internationalization: A configurational approach. Journal of Business Research, 69(11), 5473-5478.

Lau, C., \& Bruton, G. (2011). Strategic orientations and strategies of high technology ventures in two transition economies. Journal of World Business, 46(3), 371-380.

Lee, C., \& Hallak, R. (2020). Investigating the effects of offline and online social capital on tourism SME performance: A mixed-methods study of New Zealand entrepreneurs. Tourism Management, 80, 104-128

Lora, D., \& Ramírez, H. (2013). Análisis de impacto de políticas públicas para el desarrollo local en comunidades costeras y rurales: El caso de la pesca en San Blas. Revista
Iberoamericana para la Investigación y el Desarrollo Educativo, 3(6), 24.

Lumpkin, G. T., \& Dess, G. (1996). Clarifying the entrepreneurial orientation construct and linking it to performance. Academy of Management Review, 21(1), 135-172.

Marx, A., Rihoux, B., \& Ragin. C. (2014). The origins, development, and application of qualitative comparative analysis: The first 25 years. European Political Science Review, 6(1), 115-142.

McDougall, P., \& Oviatt, B. (2000). International entrepreneurship: The intersection of two research paths. The Academy of Management Journal, 43(5). 902-906.

Medina, I., Castillo, P., Alamos, P., \& Rihoux, B. (2017). Análisis cualitativo comparado (QCA). Madrid: Ed. CIS. Madrid.

Meng, F. Rieckmann, J., \& Li, C. (2016). Empirical evidence how social capital effects the internationalisation process of SME in Zhejiang. Transnational Corporations Review, 8(3), 196-206.

Meyer, K., \& Peng, M. (2016). Theoretical foundations of emerging economy business research. Journal of International Business Studies, 47, 3-22.

Musteen, M., Francis, J., \& Datta, D. K. (2010). The Influence of international networks on internationalization speed and performance: A study of Czech SMEs. Journal of World Business, 45(3), 197-205.

Nordstrom, O., \& Steier, L. (2015). Social capital: A review of its dimensions and promise for future family enterprise research. International Journal of Entrepreneurial Behavior \& Research, 21(6), 801-813.

Nuruzzaman, N., Singh, D., \& Gaur, A. S. (2020). Institutional support, hazards, and internationalization of emerging market firms. Global Strategy Journal, 10(2), 361-385.

Paul, J., \& Rosado-Serrano, A. (2019). Gradual internationalization vs born-global/international new venture models. International Marketing Review, 36(6), 830-858. 
Payne, G., Moore, C., Griffis, S., \& Autry, C. (2011). Multilevel challenges and opportunities in social capital research. Journal of Management, 37(2), 491-520.

Peña, L. J., \& Sánchez S. J. (2011). El capital social como recurso de la empresa familiar: La familiness. La Coruna, Spain: Netbiblo.

Pinho, J., \& Prange, C. (2016). The effect of social networks and dynamic internationalization capabilities on international performance. Journal of World Business, 51(3), 391-403.

Portes, A. (1998). Social capital: Its origins and applications in modern sociology. Annual Review of Sociology, 24, 1-24.

Prashantham, S., \& Young, S. (2011). Post-Entry speed of international new ventures. Entrepreneurship. Theory and Practice, 35(2), 275-292.

Racela, O. C., Chaikittisilpa, C., \& Thoumrungroje, A. (2007). Market Orientation, International Business Relationships, and Perceived Export Performance. International Marketing Review, 24(2), 144-163.

Ragin, C. (2008). Redesigning social inquiry: Fuzzy sets and beyond. Chicago: The University of Chicago.

Ragin, C. C. (2006). The limitations of net-effect thinking. In B. Rihoux, \& H. Grimm (Ed.), Innovative comparative methods for policy analysis (Chapter 2, 13-41). New York: Beyond the Quantitative-Qualitative Divide.

Ramírez, M. (2015). La pesquería de camarón en Campeche: Desarrollo histórico y perspectiva. Ciencia Pesquera, 23(1). 73-87.

Ramirez, M. \& Fonseca, M. (2010). Building social capital across generations. Family Enterprise Research Conference, Mexico, DF. Conference Num. 1

Ramos, I. G., Quintero, J. M., \& Figueroa, M. A. J. D. (2008). Empresas familiares: Sus fortalezas y debilidades. Estudio Multicaso. Asamblea General de la (ALAFEC), Tampico, Tamaulipas, México, 10. Retrieved from http:// www.alafec.unam.mx/docs/asambleas/x/ponencias/ recursos_humanos/Empresas.pdf

Rondi, E., Debellis, F., Massis, A., \& Garzoni, A. (2020). Bonding and Bridging Social Capital in Family Firm
Internalization. Sinergie. Italian Journal of Management, 38(2), 1-26.

Reyna, J. M., Vázquez, R. D., \& Valdés, A. L. (2012). Corporate governance, ownership structure and performance in Mexico. International Business Research, 5(11), 12-27.

Rienda, L., Claver, E., Quer, D., \& Andreu, R. (2019). Family businesses from emerging markets and choice of entry mode abroad: Insights from Indian firms. Asian Bus Manage, 18, 6-30.

Rihoux, B., \& Marx, A. (2013). QCA, 25 years after "the comparative method": Mapping, challenges, and innovations - mini symposium. Political Research Quarterly, 6(11). 167-235.

Rihoux, B., \& Meur, G. (2009). Crisp-set qualitative comparative analysis (csQCA). In B. Rihoux, \& C. C. Ragin (Eds.), Configurational comparative methods: Qualitative comparative analysis (QCA) and related techniques (Chapter 3). Thousand Oaks and London: Sage.

Rihoux, B., \& Ragin, C. (2008). Configurational comparative methods. Qualitative comparative analysis (QCA) and related techniques. Los Angeles: Oxford University Press.

Sabah, S., Carsrud, A., \& Kocak, A. (2014). The impact of cultural openness, religion, and nationalism on entrepreneurial intensity: Six prototypical cases of Turkish family firms. Journal of Small Business Management, 52(2), 306-324.

Sabatini, F. (2009). Social capital as social networks: A new framework for measurement and an empirical analysis of its determinants and consequences. Journal of Socio-Economics, 38(3), 429-442.

Salvato, C., \& Melin, L. (2008). Creating value across generations in family-controlled business: The role of family social capital. Family Business Review, 21(3), 259-276.

Sciascia, S., Mazzola, P., Astrachan, J. H., \& Pieper, T. M. (2012). The role of family ownership in international entrepreneurship: Exploring nonlinear effects. Small Business Economics, 38(1), 15-31.

Segaro, E., Larimo, J., \& Jones, M. (2014). Internationalisation of family small and medium-sized enterprises: The role of stewardship orientation, family commitment culture, 
and top management team. International Business Review, 23(2), 381-395.

Senik, Z., Scott-Ladd, B., Entrekin, L., \& Adham, K. (2011). Networking and internationalization of SMEs in emerging economies. Journal of International Entrepreneurship, 9(4), 259-281.

Sirmon, D. G., Arregle, J.-L., Hitt, M., \& Webb, J. W. (2008). The role of family influence in firms' strategic response to competitive threat. Entrepreneurship Theory and Practice, 32(6), 979-998.

Siying, C., \& Yiming, W. (2019). A study on the relations between Chinese government and private enterprises on the course of internationalization - A case of Huajian Group. Advances in Social Sciences Research Journal, 6(2), 275-287.

Slater, S. F., Mohr, J. J., \& Sengupta, S. (2010). Market Orientation (Wiley International Encyclopedia of Marketing [Parte 1]). New Jersey: John Wiley \& Sons.

Maciel, A. S. (2013). La empresa familiar en México. Situación actual de la investigación. Contaduría y Administración, 58(2), 135-171.

San Martin-Reyna, J. M., \& Duran-Encalada, J. A. (2012). The relationship among family business, corporate governance and firm performance: Evidence from the Mexican stock exchange. Journal of Family Business Strategy, 3(2), 106-117.

Smallbone, D., \& Welter, F. (2001). The distinctiveness of entrepreneurship in transition economies. Small Business Economics, 16(4). 249-262.

Steier, L. (2001). Family firms, plural forms of governance, and the evolving role of trust. Family Business Review, 14(4), 353-368.

Stieg, P., Cesinger, B., Apfelthaler, G., Kraus, S., \& Cheng, C. F. (2018). Antecedents of successful internationalization in family and non-family firms: How knowledge resources and collaboration intensity shape international performance. Journal of Small Business Strategy, 28(1), 14-27.

Szreter, S., \& Woolcock, M. (2004). Health by Association? Social capital, social theory, and the political economy of public health. International Journal of Epidemiology, 33(4), 650-667.

Tasavori, M., Zaefarian, R., \& Eng, T. Y. (2018). Internal social capital and international firm performance in emerging market family firms: The mediating role of participative governance. International Small Business Journal: Researching Entrepreneurship, 36(8), 887-910.

Uhlaner, L. Matser, I., Berent, M., \& Flören, R. (2015). Linking bonding and bridging ownership social capital in private firms: Moderating effects of ownership-management overlap and family firm identity. Family Business Review, 28(3), 260-277.

Vahlne, J. E., \& Johanson, J. (2013). The Uppsala model on evolution of the multinational business enterprise - From internalization to coordination of networks. International Marketing Review, 30(3), 189-210.

Vahlne, J. E., \& Johanson, J. (2019). The Uppsala model: Networks and micro-foundations. Journal of International Business Studies, 51, 4-10.

Verkuilen, J. (2005). Assigning membership in a fuzzy set analysis. Sociological Methods and Research, 33(4), 462-496.

Widmer, E. D. (2006). Who are my family members? Bridging and bonding social capital in family configurations. Journal of Social and Personal Relationships, 23(6), 979-998.

Wiklund, J., \& Shepherd, D. (2003). Knowledge-based resources, entrepreneurial orientation, and the performance of small and medium-sized businesses. Strategic Management Journal, 24(13), 1307-1314.

Woolcock, M. (2001). The place of social capital in understanding social and economic outcome the place of social capital in understanding social and economic outcome. Canadian Journal of Policy Research, 2(1), 1492-1525.

Yan, Z., Zhu, J., Fan, D., \& Kalfadellis, P. (2018). An institutional work view toward the internationalization of emerging market firms. Journal of World Business, 53(5), 682-694.

Zahra, S., \& George, G. (2002). International entrepreneurship: The current status of the field and future research agenda. In H. A. Michael, R. D., 
Ireland, S. M. Camp, \& D. L. Sexton (Ed.), Strategic Entrepreneurship: Creating a New Mindset (chapter 12, pp. 253-288). Hoboken, Nova Jersey: Blackwell Publishing Ltd.

Zahra, S. Hayton, J. \& Salvato, C. (2004). Entrepreneurship in family vs. non-family firms: A resource-based analysis of the effect of organizational culture. Entrepreneurship Theory and Practice, 28(4), 363-379.

Zapata-Cantu, L. (2020). Boosting innovation in emerging markets: The moderating role of human capital. International Journal of Emerging Markets, 1-21. doi: https://doi.org/10.1108/IJOEM-01-2019-0015 


\section{Appendix I \\ Semi-Structured Interview with Companies}

My name is Selina Salazar Cámara. I am originally from the state of Campeche and I am currently doing research at the University of Seville (Spain) to obtain a Doctor's degree in Strategic Management and International Business.

The project is supported by the Consejo Nacional de Ciencia y Tecnologì (CONACYT) in collaboration with the Government of the State of Campeche through the Pablo García Foundation.

- Research objective

The objective of the research is to understand the context in which family businesses in the fishing sector operate, their current outlook, stakeholders, and the factors that influence their internationalization towards the European Union, North America, and South America

Based on the above, a semi-structured interview will be conducted, which the respondents will answer based on their knowledge and experience. The study seeks to provide a broader understanding of the phenomenon of internationalization in the rural context.

- Participants

The participants are owners, directors, marketing managers, and export managers of seven family businesses in the fishing sector who have exported and/or export their products abroad.

The confidentiality of the answers is completely guaranteed. Participants are encouraged to respond voluntarily, so they are not under any obligation to answer all questions if they consider them intrusive. The database will be kept confidential and the names of the companies will only be revealed if the consent of all the participants is obtained.

- The interview

The interview is semi-structured and will be recorded after obtaining authorization. It covers several topics that are listed below:

- FAMILY STRUCTURE: Opinion of the interviewee about the influence and importance of the family and family relationships in the company, as well as the history of the company and wishes for succession.

- FISHING SECTOR: Opinion of the interviewee about the fishing sector based on their experience.

- INTERNATIONALIZATION AND EXPORT: Opinion of the interviewee about the challenges that the company has faced to market its products abroad.

- STAKEHOLDERS: Opinion of the interviewee about the relationships that the company maintains with its stakeholders to make exporting possible.

- HUMAN RESOURCES: Opinion of the interviewee about their work team and its strengths.

- MARKET ORIENTATION AND CUSTOMER LINKING: Opinion of the interviewee about marketing actions as well as actions oriented toward the market and links with clients.

- INTERNATIONAL ACTIVITY AND NETWORKING: Data on the presence of the company abroad.

A free copy of the results of the investigation will be made available.

THANK YOU FOR YOUR PARTICIPATION AND COOPERATION

CONSENT AGREEMENT

Seville University, Department of Business Administration and Marketing

Researcher: Selina Salazar Cámara

Company Name:

\begin{tabular}{lcc}
\hline & YES & NO \\
\hline I have received an explanation of the purpose of the investigation and the interview to be carried out. & 2. \\
I consent to participating in the project mentioned above. & 4. \\
I authorize the researcher to conduct the interview. & 5. \\
I give my permission for the interview to be recorded. & 6. \\
I give my permission for the name of the company to be used. & 8. \\
Although the answers to the interview will be confidential, I give my permission for the results of this investigation to be & 11. & 12. \\
published at the end of it. & 10. \\
\hline
\end{tabular}


SIGNATURES OF CONSENT

PARTICIPANT 1:

PARTICIPANT 2:

QUESTIONS TO OWNER OR GENERAL DIRECTOR OF THE COMPANY

FAMILY STRUCTURE was it started?

1. Can you tell me about the history of this company? Who started it and how did this come about? What year

2. How many employees do you currently have?

3. How many of these employees are family members?

4. Is family consensus needed for decision making or to implement a new strategy?

5 . Has there been a generational change since the founding of your company?

6. Is there a desire for the following generations to continue in the company? What are the expectations regarding generational succession?

FISHING SECTOR

7. What do you think of the fishing sector in Campeche? What do you think are your main strengths and weaknesses? INTERNATIONALIZATION AND EXPORTING

8. To take your products abroad, do you use exporting or some other mode of entry?

9. Of all the products produced by your company, which ones are exported?

10. In which countries is your family business present? What was the initial contact like?

11. What actions did you take to make internationalization possible? Was any certification necessary? For what?

12. What are the main barriers you faced when you decided to internationalize your company (economic, cultural, personal, etc.)?

13. What are the general risks that your company faced when it internationalized?

14. What are your future expectations in international markets?

15. What lessons from your company's internationalization process could serve other companies?

STAKEHOLDERS

16. What players are involved from the capture of your product until it reaches its destination?

17. Regarding the fishermen, what do you consider are the main strengths and weaknesses of your relationship with them?

18. How do you search for international clients? How did you manage to establish contact with them?

19. Who are your main customers? Could you mention three or four?

20. What advantages do you provide to your clients, who choose you over the competition (innovation in products, quality, presentation, delivery, formality, punctuality, etc.)?

21. Do you believe that being a family business provides more reliability to your customers? Why?

22. Do you take into account your competence to make decisions in your company? What kind of relationship do you have? Do you help each other? Do rivalries exist?

23. Have you received any support from government institutions or other associations (advice or subsidies etc.)?

24. Are you aware of any companies or institutions that are dedicated to supporting exports and what do they provide?

25. What would you say are the pros and cons of your relationship with these institutions?

26. Do you have non-family investors in your company? How is your capital constituted?

27. Do you use external services in the production and export process? Do you hire other companies to help in advising, marketing, or any specific service? What is this relationship like?

28. Did these networks of contacts come from previous generations or did you generate them in your administration? HUMAN RESOURCES

29. Considering that this is a family company that also has external employees, do you think that there is any difference in the treatment of them? 
30. Are the employees of your company asked for specific training to do with exporting? Do you provide them with any complementary training at the company?

31. What do you consider to be the virtues of your team (commitment, risk tolerance, skills, global vision, etc.)?

32. As a family company, are there any established values, norms of conduct, or any code that identifies it as a family company? Does the family engage in any rituals or very personal practices within the company?

MARKET ORIENTATION AND CUSTOMER LINKING ASPECTS

33. Have you introduced new products in recent years? What are these products?

34. What are the criteria you use to determine which products to release (customer needs, industry preferences, etc.)?

35. How do you obtain information about the preferences of your customers or future customers (events, news, competition, fairs)?

36. Whenever products are ready, what marketing actions do you launch in the company to advertise its products (fairs, advertising, events, etc.)?

37. Are the people in the organization who interact with the customers aware of its preferences and history?

38. How are relationships with customers maintained and fed in order to retain them? How do you keep them happy (tracking, rewards, etc.)?

39. Is after-sales service given or is satisfaction monitored once the product is received?

INTERNATIONAL ACTIVITY AND NETWORKING

40. How many countries do you export to?

41. Estimated number of partners abroad

42. Number of clients abroad

43. What is your export volume (weights and tons)?

44. Approximately what percentage of total sales do these figures represent? 


\section{Conflicts of interest:}

The authors have no conflict of interest to declare.

\section{Copyrights:}

RBGN owns the copyrights of this published content.

\section{Plagiarism analysis:}

RBGN performs plagiarism analysis on all its articles at the time of submission and after approval of the manuscript using the iThenticate tool.

\section{Authors:}

1. Selina Salazar Cámara, Ph.D. Student, University of Seville, Seville, Spain.

E-mail: sselyna@hotmail.com

2. David Martín, Ph.D., University of Seville, Seville, Spain.

E-mail:dmartin@us.es

3. Francisco J. Acedo Gonzalez, University of Seville, Seville, Spain.

E-mail: fjacedo@us.es

\section{Authors' Contributions:}

1. Selina Salazar Cámara: Definition of research problem; Development of hypotheses or research questions (empirical studies); Development of theoretical propositions (theoretical work); Definition of methodological procedures; Data Collection; Literature review; Statistical analysis; Analysis and interpretation of data; Critical revision of the manuscript; Manuscript writing.

2. David Martín: Definition of research problem; Development of hypotheses or research questions (empirical studies); Development of theoretical propositions (theoretical work); Definition of methodological procedures; Literature review; Statistical analysis; Analysis and interpretation of data; Critical revision of the manuscript; Manuscript writing.

3. Francisco J. Acedo Gonzalez: Definition of research problem; Development of hypotheses or research questions (empirical studies); Development of theoretical propositions (theoretical work); Literature review; Analysis and interpretation of data; Critical revision of the manuscript; Manuscript writing. 